\title{
IMPACT OF COVID-19 PANDEMIC ON EDUCATION SYSTEM
}

\author{
Bhavya Bhasin*1, \\ ${ }^{\text {*} S}$ Student, Masters of Clinical Psychology, Lovely Professional University, Phagwara, Punjab, India \\ Gautam Gupta*2, \\ $*^{2}$ Project Engineer, Wipro Limited, Chennai, Tamil Nadu, India \\ (Alumni, Mechatronics Engineer, Thapar Institute of Engineering \& Technology, Patiala, Punjab, India) \\ Sumedha Malhotra $*^{3}$
$*^{3}$ Student, Masters of Science (IT), Government College for Girls (Affiliated with PU), Ludhiana, Punjab, India
}

Article DOI: https://doi.org/10.36713/epra6363

\begin{abstract}
In India, the technology has entered in the realm of education in 1980s. As people use radios and television to get more and more knowledge but this is not noticeable. But because of COVID-19 Pandemic, now people are able to notice the technology like online platforms to overcome the challenges face by students in education. But online platforms are challenging for students in some way. This present article helps to portray the advantages and disadvantages of online learning and how students, teachers and society are trying to accept the new education platforms. Online learning is just come into limelight after COVID-19 Pandemic.
\end{abstract}

KEYWORDS: Coronavirus, COVID-19, Lockdown, Education, School.

\section{INTRODUCTION}

As the COVID-19 Pandemic attacks the world, it is fundamental to take care of the instructive requirements of youngsters and youth during the emergency. COVID illness 2019 (COVID-19) is a possibly extreme intense respiratory disease brought about by the novel serious intense respiratory condition (SARSCoV2). It has been announced a pandemic by the World Wellbeing Organization (WHO). 4.5 million people are affected from COVID-19. Due to COVID-19, government has been extending the lockdown period. The instructive establishments all through the country have never got any unwinding to start their instructive exercises. This Pandemic influences altogether the training area. Pandemic has impacted around 1.2 billion students by university and school closure. More than 32 crore of students in India have been affected by the national lockdown for COVID-19.

This lockdown has affected radically the world's understudy populace. According to Human Resource Development, it was observed that there are 39931 colleges, 10725 institutions and 993 recorded on their entryway, which add to schooling (DNS Kumar, 2020). The nation has been adjusting to better approach for learning. Only 45 crore people of total population have admittance to the e-learning/web. Numerous individuals who live in rustic territories are still particularly unprivileged of the advancements and hinder the reason for online training. Because of COVID-19 Pandemic, instructive organizations embrace web-based learning and virtual learning society. Even the students, who registered in many Universities abroad, are now leaving those countries. 


\section{LITERATURE REVIEW}

Pravat (2020) found that the educational institutions get closed and created many challenges for students and professors. Along these lines, the exercises like assessments, entrance tests, serious assessments, and confirmations led by numerous universities, schools, and colleges are dropped. Pravat (2020b) revealed that the students and teachers expanded the utilization of web for sharing data by utilizing Google drive, WhatsApp, Twitter, Telegram etc. The Pandemic has made it hard for scientists to travel and cooperate with others. Some project is made complicated to do because of joint research and also scientific laboratory research work would not be conducted. E-conferences and Webinars became normal for sharing their academic ideas. They increased their skills for publishing their books and articles in their free time.

Pravat (2020a) said that with an increment of joblessness, the instructive interest may diminish as individuals' battle for food. The University Grants Commission have launch virtual platforms like e-books, online teaching, learning materials and many more ways to continue their learning. Most of the students take help from social tools like Zoom, Telegram, Google meet, WhatsApp and Youtube Live for online teaching and learning system. Bhattacharya (2020) found that the higher education sector faces unique challenges even after the lockdown. The fear of infection has wrecked institutions for now: as colleges and universities closed down. The effect of the COVID-19 Pandemic on higher education might be long lasting (Jena, 2020). Suresh (2020) found that COVID-19 Pandemic has totally fall the entire world economy. Srivastava (2020) revealed that most of the industries have come to stop.

This pandemic not only affect the economic and financial aspect of society but also teacher and students' psychological aspect. Cao et al, 2020 found that online learning creates an effect on students' growth. By using online platforms for learning and teaching purposes can enhance their capabilities. Chan et al., 2006 showed that technology allows students to learn or get more knowledge. Fynewever (2008); Lunsford \& Pendergrass (2016) revealed that online system allows teachers to decrease the time spent grading all students project or assignments, check their learning progress. (Stone, Taylor M., Chaney S.P., 2011) found that online platform for teaching and learning is cost-efficient. Singh \& Pan (2004) revealed that online platform is the way to help to the undeserved students. There are number of apps to be used for learning-teaching purpose.

Lim, Zhao, Tondeur, Chai \& Tsai (2013); Proctor \& Marks (2013) found that digital games or tools for learning and teaching are increasing day by day. Palloff \& Pratt (2007) revealed that students and teachers trying to overcome challenges in education system using various types of technology. Even the online library resources as well as sites will help the students to get more and more knowledge. Bao (2019); Bao \& Zhang (2012) found that online learning has many advantages but it has disadvantages also. Bailey et al., 2014 said that online students and on-campus have clear gaps. Price (2006) revealed that men are less interested in online study modes as compared to women. Singh \& Pan (2004) highlights that women are more interested in part-time online courses as compare to men. Daymont et al, (2011); Jaggars (2014); Hirschheim (2005) said that online platforms are more flexible.

Kumar (2020); Aman \& Shirvani (2006); Bambara et al. (2009) highlight that the students who live in distant places face difficulty to follow the online teaching and also making their experience frustrating. Sun (2014) revealed that online learning is uncommon. Zhang \& Lin (2020); Romanowski (2010); Nicol \& Sinclair (2003) investigate that there is less interaction and discussion in online mode. Li, Wu, Yao \& Zhu (2013) highlight that to check on the interest of weak students in an online class. Hiltz, Coppola, Rotter, Turoff \& Benbunan-Fich (2000); Lock (2006) indicated that professors or teachers could use group project work to increase online learning for those students who were less motivated. Paulus (2005) revealed that teachers should make their class interactive, creative and fun filled.

\section{CONCLUSION}

After studying all the reviews it can be predicted that there are high chances of increasing disturbance in education of students. Even students are experiencing many obstacles in opting new method of learning. Somewhere, students are not able to interact with their teachers effectively. Teachers are not able to give attention to all the students. But there are advantages also. As, students are exploring more opportunities by increasing their knowledge. Everyone take their time to adapt this new platform of learning and deal with the situation effectively.

\section{REFERENCES}

1. Pravat Ku Jena. Challenges and Opportunities created by Covid-19 for ODL: A case study of IGNOU. International Journal for Innovative Research in Multidisciplinary Filed. 2020a; 6(5):217-222.

2. Pravat Ku Jena. Impact of Pandemic COVID-19 on Education in India. Purakala. 2020b; 31(46):142-149.

3. Pravat Ku Jena. Online learning during lockdown period for Covid-19 in India. International Journal of Multidisciplinary Educational Research. 2020c; 9, 5(8):82-92 
4. Bhattacharya. R, (2020). The COVID-19 pandemic and its likely impact on Higher Education. Retrieved on July 17, 2020. From https://www.abpeducation.com/expert-views/the-covid-19- pandemic-and-its-likely-impact-onhigher-education-1.1168731

5. Jena, P. K. (2020). Impact of Covid-19 on higher education in India. International Journal of Advanced Education and Research, Volume 5; Issue 3; 2020; Page No. 77-81

6. $\mathrm{Li}, \mathrm{Y}$., Wu, S., Yao, Q., \& Zhu, Y. (2013). Research on college students'online learning behavior. e-Education Research, 34(11), 59-65.

7. Singh P, Pan W. (2004). Factors affecting student adoption of online education. Academic Exchange Quarterly, 8(1), 7-10. 91.

8. Srivastava Ankita, Raghvendra Kumar Sharma, and Arjun Suresh. Impact of COVID-19 on Sustainable Development Goals.(2020)

9. Stone, Mischelle Taylor and Suzanne Perumean-Chaney. 2011. The Benefits of Online Teaching for Traditional Classroom Pedagogy: A Case Study for Improving Face-to-Face Instruction. MERLOT Journal of Online Learning and Teaching 7, (3): 393-400.

10. Suresh, Arjun, Diksha Chauhan, Amina Othmani, Neha Bhadauria, S. Aswin, Jais Jose, and Nezha Mejjad. Diagnostic Comparison of Changes in Air Quality over China before and during the COVID-19 Pandemic. (2020).

11. M.L. Lunsford M. Pendergrass Making online homework work Primus, 26 (6) (2016), pp. 531-544. https://doi.org/10. 1080/10511970.2015.1110219

12. Cao W, Fang Z, Hou G, Han M, Xu X, Dong J, Zheng J. (2020). The Psychological Impact of the COVID-19 Epidemic on College Students in China. Psychiatry Research, 287, 1-5. https://doi.org/10.1016/j.psychres.2020.11 2934

13. Singh P, Pan W. (2004). Factors affecting student adoption of online education. Academic Exchange Quarterly, 8(1), 7-10

14. Palloff R. and Pratt K. (2007). Building online learning communities. San Francisco, CA: Jossey-Bass.

15. Bao W. (2019). Bridging the gap between research and practice: Identifying high impact educational practices for Chinese undergraduate education. Peking University Education Review, 1, 105-129. 10.

16. Bao W, Zhang X. (2012). The multi-dimensional structure and influence mechanism of student academic involvement in China. Fudan Education Forum, 6, 20-28.

17. Daymont T, Blau G, Campbell D. (2011). Deciding between traditional and online formats: Exploring the role of learning advantages, flexibility, and compensatory adaptation. Journal of Behavioral and Applied Management, $12(2), 156-175$.

18. Fynewever A comparison of the effectiveness of web-based and paperbased homework for general chemistry. The Chemical Educator, 13 (2008), pp. 264-269.

19. Hirschheim R. (2005). The internet-based education bandwagon: Look before you leap. Communications of the ACM, 48(7), 97-101. https://doi.org/10.1080/08923 647.2014.867697

20. Jaggars SS, Xu D. (2016). How do online course design features influence student performance? Computers \& Education, 95, 270-284.

21. Kumar S. (2020) 5 Common Problems Faced by Students In eLearning And How To Overcome Them. E Learning Industry. https://elearningindustry.com/5-commonproblems-faced-by-students-in-elearningovercome

22. Aman JR, Shirvani, S. (2006). Dick and Jane online: Considering online course. Journal of Computing Sciences in Colleges, 21(3), 131-138.

23. Bambara CS, Harbour CP, Davies TG, Athey S. (2009). Delicate engagement: The lived experience of community college students enrolled in high-risk online courses. Community College Review, 36(3), 219-238.

24. Sun SYH. (2014). Learner Perspectives on Fully Online Language Learning. Distance Education, 35(1), 18-42. https://doi.org/10.1080/01587919. 2014.891428

25. Zhang Y, Lin, C.-H. (2020). Student interaction and the role of the teacher in a state virtual high school: what predicts online learning satisfaction? Technology, Pedagogy \& Education, 29(1), 5771.https://doi.org/10.1080/1475939X.20 19.1694061.

26. Nicol D, Minty I, Sinclair C. (2003). The social dimensions of online learning. Innovations in Education and Teaching International, 40(3), 270-280. http://dx.doi.org/10.1080/1470329032000103807

27. Li Y, Wu S, Yao Q, Zhu Y. (2013). Research on college students' online learning behavior. e-Education Research, 34(11), 59-65.

28. Hiltz SR, Coppola N, Rotter N, Turoff M, Benbunan-Fich R. (2000). Measuring the importance of collaborative learning for the effectiveness of ALN: A multimeasure, multi-method approach. Journal of Asynchronous Learning Networks, 4(2), 103-123.

29. Lock J. (2006). A new image: Online communities to facilitate teacher professional development. Journal of Technology and Teacher Education, 14(4), 663-678. 67. M Bower.

30. Paulus T.M. (2005) Collaborative and cooperative approaches to online group work: The impact of task type. Distance Education, 26(1), 111-125. https://doi.org/10.1080/01587910500081343 